\title{
Catellatospora matsumotoense sp. nov. and C. tsunoense sp. nov., Actinomycetes Found in Woodland Soils
}

\author{
KOZO ASANO, ${ }^{1 *}$ IZUMI MASUNAGA, ${ }^{2}$ AND ISAO KAWAMOTO ${ }^{3}$ \\ Foods and Liquors Research Laboratories, Kyowa Hakko Kogyo Co., Ltd., 404I, Ami-Machi, Inashiki-Gun, Ibaraki, \\ Japan 300-031' ; Miles-Kyowa Co., Ltd., 1-2-3 Kita-Aoyama, Minatoku, Tokyo, Japan 107²; and Tokyo Research \\ Laboratories, Kyowa Hakko Kogyo Co., Ltd., 3-6-6 Asahi-Machi, Machida, Tokyo, Japan $194^{3}$
}

\begin{abstract}
Two new species in the genus Catellatospora are proposed. These organisms differ in carbon utilization profiles, vitamin requirements for growth, and levels of deoxyribonucleic acid relatedness to previously described species. The new species Catellatospora matsumotoense (type strain 6393-C [ = IFO 14550]) contains menaquinones with 10 isoprene units $(\mathrm{MK}-10)$ as its major respiratory quinones, contains 3-O-methylrhamnose in its cell walls, is resistant to novobiocin, does not require thiamine for growth, and uses fructose and raffinose but not mannitol, $\alpha$-methyl-D-glucoside, or rhamnose as a sole carbon source. The new species Catellatospora tsunoense (type strain 6420-P [ = IFO 14552]) contains menaquines with nine isoprene units (MK-9) as its major menaquinones, does not contain 3-O-methylrhamnose, is susceptible to novobiocin, requires thiamine for growth, and uses fructose, raffinose, and rhamnose but not mannitol or $\alpha$-methyl-D-glucoside as a sole carbon source.
\end{abstract}

The members of the genus Catellatospora, a genus belonging to the Actinomycetales, form chains of nonmotile spores arising from the vegetative hyphae on the surfaces of agar media, lack true aerial mycelia, and have type II cell wall amino acids (7) (meso- and 3-hydroxydiaminopimelic acids and glycine), a glycolyl type of cell wall sugar (13), pattern D whole-cell sugars (xylose and arabinose) (7), and a type PII phospholipid pattern (phosphatidylethanolamine as the major nitrogenous phospholipid) $(1,8)$.

Species of this genus are divided into two groups; the members of one group contain menaquinones with 10 isoprene units (MK-10) and 3-O-methylrhamnose, and the members of the other contain MK-9 but lack 3-O-methylrhamnose (3). The previously proposed species Catellatospora ferruginea is a member of the former group, and Catellatospora citrea and C. citrea subsp. methionotrophica are members of the latter group (1-3).

To examine the variations in taxonomic characteristics among organisms belonging to the genus Catellatospora, the type strains of the species mentioned above and other isolates were compared with respect to physiological, morphological, biochemical, and cultural properties. We found that novobiocin susceptibility, nutrient requirements, and carbon utilization profiles could be used to characterize the taxonomic positions of the strains.

A total of 12 isolates were assigned to previously described species, but 2 isolates, strains $6393-C^{T}(T=$ type strain) and $6420-\mathrm{P}^{\mathrm{T}}$, clearly differed from the previously described species in their carbohydrate utilization profiles and vitamin requirements. Based on the results of deoxyribonucleic acid (DNA)-DNA hybridization, these strains are proposed as new Catellatospora species.

\section{MATERIALS AND METHODS}

Bacterial strains used in this study. The following 18 strains of the genus Catellatospora were used: $C$. citrea $6183-\mathrm{E}^{\mathrm{T}}(=$ IFO $14495^{\mathrm{T}}$ ) (1) and our $C$. citrea isolates $6188-\mathrm{B}, 6198-\mathrm{A}$, 6198-B, 6252-E, and 6479-A; $C$. citrea subsp. methionotrophica $6257-\mathrm{B}^{\mathrm{T}}\left(=\right.$ IFO $\left.14553^{\mathrm{T}}\right)(2)$ and $6498-\mathrm{D}(2) ; C$.

\footnotetext{
* Corresponding author.
}

ferruginea $6257-\mathrm{C}^{\mathbf{T}}\left(=\mathrm{IFO} 14496^{\mathrm{T}}\right)(1)$ and our $C$. ferruginea isolates 6168-B, 6183-F, 6248-A, 6423-A, 6432-C, 6464-O, and 6479-B; Catellatospora matsumotoense 6393- $\mathrm{C}^{\mathrm{T}}$; and Catellatospora tsunoense $6420-\mathrm{P}^{\mathrm{T}}$.

Species of two other genera, Streptomyces olivaceus ATCC 12019 and Micromonospora olivasterospora ATCC $21819^{\mathrm{T}}$, were used as references in DNA relatedness studies.

Physiological, morphological, and chemotaxonomic properties. The procedures used for carbon utilization, antibiotic susceptibility, enzyme activity, and other physiological tests and the method used for scanning electron microscopy have been previously described (1).

Vitamin requirements were examined by adding various vitamins to a basal medium containing (per liter of distilled water) $10 \mathrm{~g}$ of glucose, $5 \mathrm{~g}$ of ammonium sulfate, $1 \mathrm{~g}$ of monobasic potassium phosphate, $2 \mathrm{~g}$ of dibasic potassium phosphate, $0.5 \mathrm{~g}$ of magnesium sulfate, $0.1 \mathrm{~g}$ of sodium chloride, $0.1 \mathrm{~g}$ of calcium chloride, $500 \mu \mathrm{g}$ of boric acid, 40 $\mu \mathrm{g}$ of copper sulfate, $100 \mu \mathrm{g}$ of potassium iodide, $200 \mu \mathrm{g}$ of ferric chloride, $400 \mu \mathrm{g}$ of manganese sulfate, $200 \mu \mathrm{g}$ of sodium molybdate, and $400 \mu \mathrm{g}$ of zinc sulfate. The vitamins examined were biotin, calcium pantothenate, folic acid, inositol, niacin, $p$-aminobenzoic acid, pyridoxine hydrochloride, riboflavin, and thiamine.

Menaquinone compositions and cultural characteristics were determined as described previously (1).

DNA base composition and homology. DNA was extracted from microorganisms by using the method of Marmur (9). Guanine-plus-cytosine $(\mathrm{G}+\mathrm{C})$ contents of purified DNAs were calculated from their thermal denaturation midpoints in $0.1 \times \mathrm{SSC}$ buffer $(1 \times \mathrm{SSC}$ is $0.15 \mathrm{M} \mathrm{NaCl}$ plus $0.015 \mathrm{M}$ sodium citrate) by using the method of Marmur and Doty (10).

DNA was further treated with proteinase $\mathrm{K}$ before precipitation in polyethylene glycol 6000 with $\mathrm{NaCl}$ and was subsequently washed repeatedly with $70 \%$ ethanol. Doublestranded DNA was broken into fragments of 2 to 4 kilobases by sonication (one 15-s burst) in ice-cold water. DNA was labeled by nick translation, using a ${ }^{32} \mathrm{P}$ nick translation kit (Takara Shuzo Co., Ltd., Kyoto, Japan). DNA-DNA hybridization was performed by using the procedure described by Hopwood et al. (5). 
TABLE 1. Menaquinone compositions of strains of Catellatospora species

\begin{tabular}{|c|c|c|c|c|c|c|c|c|c|c|c|c|}
\hline \multirow{3}{*}{ Strain } & \multicolumn{12}{|c|}{$\%$ Content of: } \\
\hline & \multicolumn{3}{|c|}{ MK-7 } & \multicolumn{3}{|c|}{ MK-8 } & \multicolumn{3}{|c|}{ MK-9 } & \multicolumn{3}{|c|}{ MK-10 } \\
\hline & $\mathrm{H}_{4}$ & $\mathrm{H}_{6}$ & $\mathrm{H}_{8}$ & $\mathrm{H}_{4}$ & $\mathrm{H}_{6}$ & $\mathrm{H}_{8}$ & $\mathrm{H}_{4}$ & $\mathrm{H}_{6}$ & $\mathrm{H}_{8}$ & $\mathrm{H}_{4}$ & $\mathrm{H}_{6}$ & $\mathrm{H}_{8}$ \\
\hline 6479-B & & & & & & & & & 6 & & & 94 \\
\hline 6423-A & & & & & & 14 & & & & & & 86 \\
\hline $6464-\mathrm{O}$ & & & & & & & & & & 21 & 35 & 44 \\
\hline $6248-A$ & & & 5 & & & 3 & & & 12 & & 3 & 77 \\
\hline $6183-\mathrm{F}$ & & & & & & & & & 9 & & & 91 \\
\hline 6168-B & & & & & 2 & 5 & 3 & 7 & 10 & 4 & 22 & 47 \\
\hline $6432-C$ & & & & 2 & 2 & 1 & 1 & 5 & 5 & 11 & 40 & 31 \\
\hline $6393-C^{T}$ & & 4 & 5 & 5 & 5 & 4 & 2 & 4 & 2 & 17 & 29 & 23 \\
\hline 6198-A & 5 & 1 & & 1 & & & 62 & 23 & 7 & & & \\
\hline 6479-A & & & & & & & 66 & 27 & 8 & & & \\
\hline $6252-\mathrm{E}$ & & & & 6 & 2 & 4 & 60 & 22 & 6 & & & \\
\hline 6188-B & & & & & & & 83 & 17 & & & & \\
\hline 6198-B & & & & & & & 75 & 19 & 6 & & & \\
\hline $6420-\mathrm{P}^{\mathrm{T}}$ & & & & & & & 60 & 36 & & & 4 & \\
\hline
\end{tabular}

The reference and labeled DNAs were denatured in alkali $(0.83 \mathrm{M} \mathrm{NaOH})$ and neutralized with $\mathrm{HCl}$ after addition of a tris(hydroxymethyl)aminomethane hydrochloride buffer $(0.62$ $\mathrm{M}, \mathrm{pH}$ 8.2). The reference DNA was fixed on nylon membrane disks (Gene Screen Plus; Du Pont Co., Wilmington, Del.) and incubated with the labeled DNA at $70^{\circ} \mathrm{C}$ for $18 \mathrm{~h}$ with agitation in a hybridization mixture containing $0.02 \%$ polyvinylpyrrolidone (average molecular weight, 40,000; Sigma Chemical Co., St. Louis, Mo.), $0.02 \%$ bovine serum albumin fraction V, 0.02\% Ficoll (Pharmacia LKB Biotechnology, Uppsala, Sweden), and calf thymus DNA prepared in $6 \times \mathrm{SSC}$. The nylon membranes were washed three times with $2 \times \mathrm{SSC}$ at $50^{\circ} \mathrm{C}(15 \mathrm{~min}$ each) and air dried, and the number of radioactive counts per minute was determined with a liquid scintillation counter in a scintillation fluid containing $4 \mathrm{mg}$ of Omniflvor (Du Pont) per $\mathrm{ml}$ in toluene. DNA from Escherichia coli strain B (Sigma) was used as a reference.

\section{RESULTS}

Menaquinone composition. Tetra- and hexahydrogenated menaquinones were the major components in strains containing 9 isoprene units, whereas hexa- and octahydrogenated menaquinones were predominant in strains containing 10 isoprene units (Table 1).

Morphology. Globose bodies, which were morphologically similar to the globose bodies of members of the genus Dactylosporangium described by Thiemann et al. (12) and by Sharples and Williams (11), were formed by strain 6420 $\mathrm{P}^{\mathrm{T}}$ and $C$. ferruginea $6168-\mathrm{A}$ on tap water agar medium and were 0.4 to $0.6 \mu \mathrm{m}$ in diameter (Fig. 1a and b). As a typical example of the spore chain morphology of this genus, spore chains of strain 6420-P $\mathrm{P}^{\mathrm{T}}$ are shown in Fig. 2.

All isolates sporulated on tap water agar medium in 10 days to 1 month at $28^{\circ} \mathrm{C}$, and many strains sporulated on calcium malate agar medium, but the ability to sporulate varied among the strains. The level of sporulation decreased from cultures grown on poor media to cultures grown on rich complex organic media.

Physiological properties. The physiological properties of the strains which we tested are shown in Table 2 . Novobiocin susceptibility correlated both with menaquinone composition and the presence of 3-O-methylrhamnose. A thiamine
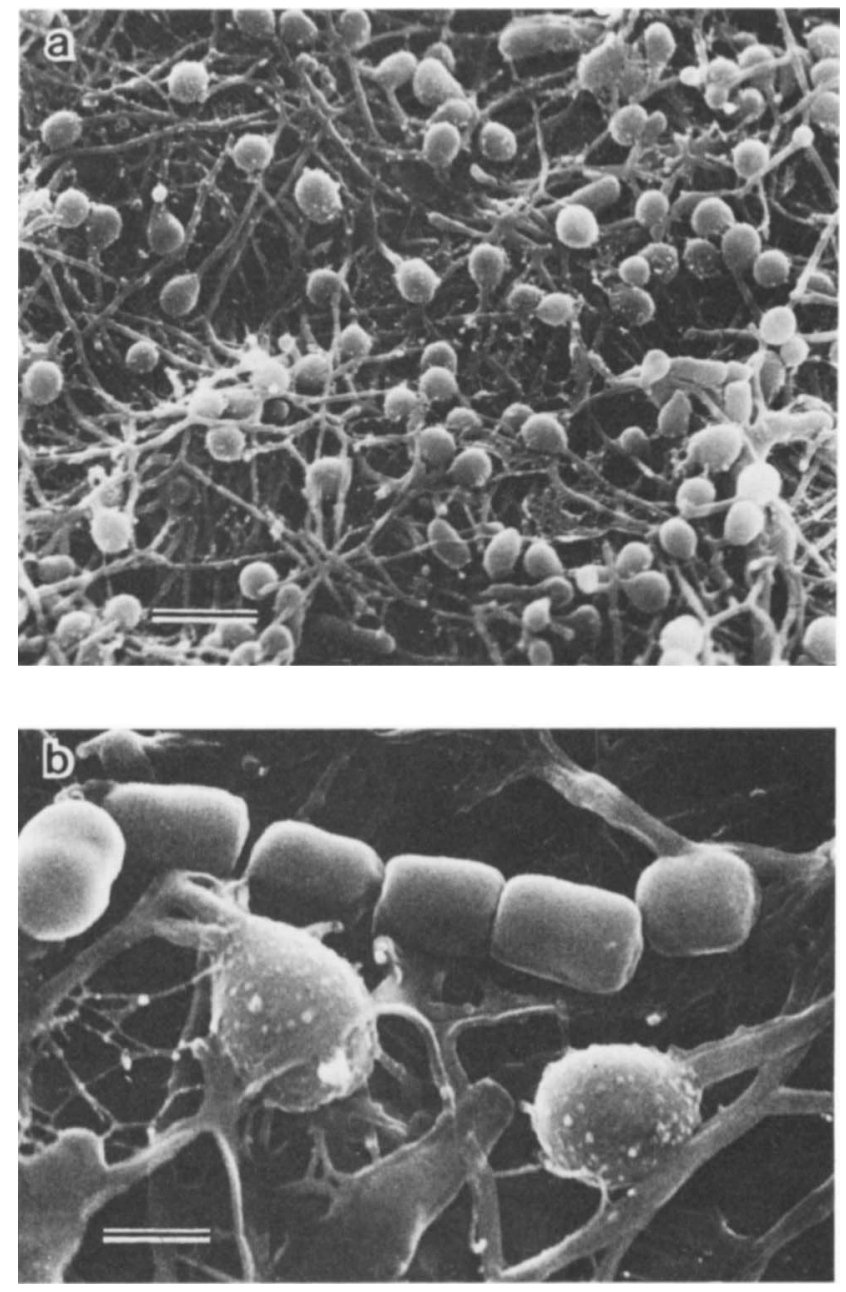

FIG. 1. (a) Scanning electron micrograph of globose bodies of $C$. tsunoense $6420-\mathrm{P}^{\mathrm{T}}$ growth on tap water agar for 2 weeks at $28^{\circ} \mathrm{C}$. Globose bodies were produced abundantly. Bar $=2.0 \mu \mathrm{m}$. (b) Spores (upper part of the photograph) and globose bodies formed at the ends of branches of vegetative hyphae. Bar $=0.5 \mu \mathrm{m}$.

requirement was apparent for all of the strains containing MK-10 except strain $6393-C^{\mathbf{T}}$, whereas only one of the strains containing MK-9 (strain $6420-\mathrm{P}^{\mathrm{T}}$ ) required this compound.

Carbon utilization was examined with 28 compounds. The responses to 12 compounds varied depending on the strain (Table 2). Distinctive features were revealed in utilization profiles. None of the strains belonging to the MK-9 group except strain $6420-\mathrm{P}^{\mathrm{T}}$ grew on $\mathrm{D}$-fructose and raffinose; strain $6420-\mathrm{P}^{\mathrm{T}}$ grew as abundantly as strains belonging to the MK-10 group. All of the strains of the MK-10 group except strain $6393-C^{\mathrm{T}}$ grew abundantly on D-mannitol, $\alpha$-methylD-glucoside, and L-rhamnose. All of the strains exhibited good growth on L-arabinose, cellobiose, D-galactose, Dglucose, maltose, D-mannose, starch, and D-xylose, poor to no growth on meso-erythritol, ethanol, methanol, and Dsorbitol, and unclear or graded responses on D-arabinose, melibiose, salicin, and sucrose. Utilization of the last four compounds could not be used for taxonomic characterization of the strains.

In other physiological tests, there were insignificant differences among the strains. All of the strains grew at $\mathrm{pH} 6$ to 


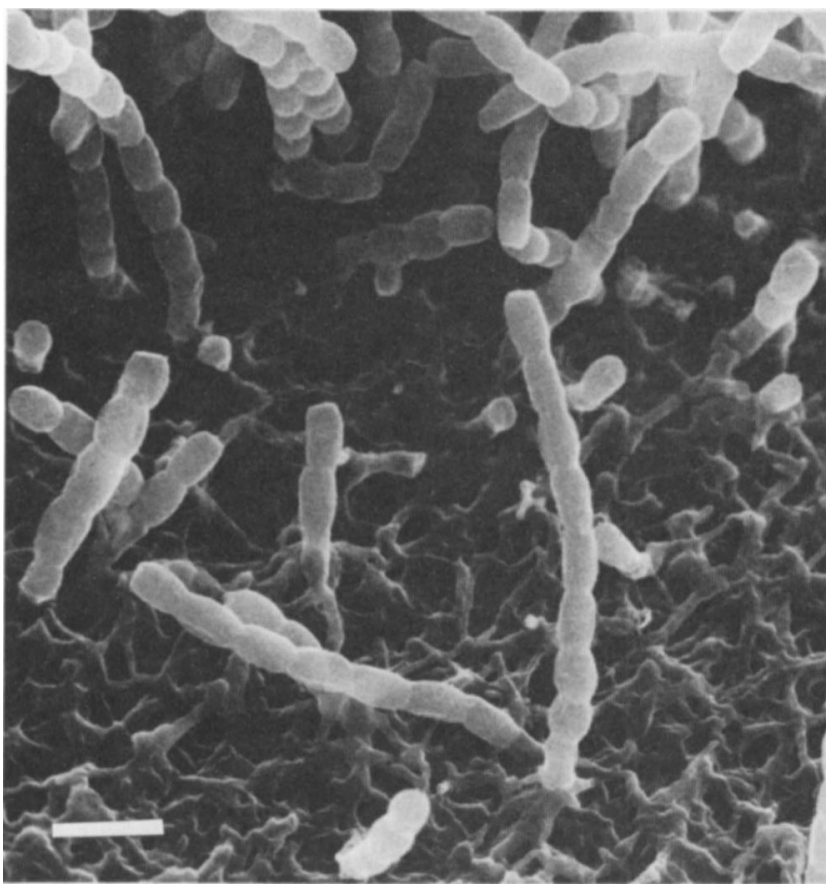

FIG. 2. Scanning electron micrograph of spore chains formed from vegetative mycelia of $C$. tsunoense $6420-\mathrm{P}^{\mathrm{T}}$ grown on tap water agar for 2 weeks at $28^{\circ} \mathrm{C}$. Bar $=2.0 \mu \mathrm{m}$.

9 and under mesophilic conditions $\left(20\right.$ to $\left.34^{\circ} \mathrm{C}\right)$ and did not grow on media supplemented with $\mathrm{NaCl}(3 \%)$, lysozyme $(0.005 \%)$, crystal violet $(0.001 \%)$, and sodium lauryl sulfate $(0.01 \%)$. They were susceptible to 6-demethyltetracycline $(500 \mu \mathrm{g} / \mathrm{ml})$, gentamicin $(50 \mu \mathrm{g} / \mathrm{ml})$, streptomycin $(100 \mu \mathrm{g} /$ $\mathrm{ml})$, and vancomycin $(50 \mu \mathrm{g} / \mathrm{ml})$. They did not liquefy gelatin and did not peptonize milk (except $C$. citrea $6183-\mathrm{E}^{\mathrm{T}}$ ). They exhibited positive activity for leucine arylamidase, $\beta$-galactosidase, $\alpha$-glucosidase, and $\beta$-glucosidase, but low or negative activity for cystine arylamidase, $\alpha$-fucosidase, and $\beta$-glucuronidase.

Cultural characteristics. The colors of well-grown vegetative mycelia of members of the MK-10 group were usually orange to reddish brown under various growth conditions, whereas strain 6393- $\mathrm{C}^{\mathrm{T}}$ exhibited a mustard gold color on nutrient agar and a cream color on glucose-asparagine agar. On the other hand, in the MK-9 group the mycelial colors were usually yellow, but $C$. citrea 6188 -B and 6198-B were brownish orange on oatmeal agar and glucose-yeast extract agar. Pastel orange was observed with strain $6420-\mathrm{P}^{\mathrm{T}}$ on glucose-yeast extract agar. Table 3 shows the macroscopic appearance of strains $6393-\mathrm{C}^{\mathrm{T}}$ and $6420-\mathrm{P}^{\mathrm{T}}$ on various culture media.

The mycelial pigments were extractable with acetone or chloroform plus methanol $(2: 1, \mathrm{vol} / \mathrm{vol})$ and gave a number of spots ranging in color from yellow to orange on silica gel thin-layer chromatograms developed with a chloroformmethanol-water $(70: 35: 7, \mathrm{vol} / \mathrm{vol})$ solvent system. Most of the pigments extracted from orange mycelia grown aerobically in liquid medium (3) gave $R_{f}$ values similar to those of pigments extracted from yellow mycelia, but the amounts of the pigments varied depending on the strain. Extracts from yellowish strains contained the orange pigments found in extracts from orange strains, but their amounts were less than those from the orange strains. This result suggested that the difference in mycelial color between yellow and orange strains was caused by differences in the combination profiles of pigmental substances for the strains but not by the substances themselves.

A soluble pigment, which was produced only by strain 6393- $\mathrm{C}^{\mathrm{T}}$, was reddish brown on oatmeal agar and a mustard gold color on nutrient agar.

Production of a melanoid pigment was usually negative, but a small amount of pigment was produced on tyrosine

TABLE 2. Comparison of characteristics of Catellatospora species

\begin{tabular}{|c|c|c|c|c|c|}
\hline \multirow[b]{2}{*}{ Characteristic } & \multicolumn{5}{|c|}{$\%$ of strains positive } \\
\hline & $\begin{array}{l}\text { C. citrea } \\
\text { (6 strains) }\end{array}$ & $\begin{array}{l}\text { C. citrea subsp. } \\
\text { methionotrophica } \\
\quad(2 \text { strains })\end{array}$ & $\begin{array}{l}\text { C. tsunoense } \\
\text { (1 strain) }\end{array}$ & $\begin{array}{l}\text { C. ferruginea } \\
\text { (8 strains) }\end{array}$ & $\begin{array}{c}\text { C. matsumotoense } \\
\text { (1 strain) }\end{array}$ \\
\hline \multicolumn{6}{|l|}{ Major menaquinone } \\
\hline MK-9 & 100 & 100 & 100 & 0 & 0 \\
\hline $\mathrm{MK}-10$ & 0 & 0 & 0 & 100 & 100 \\
\hline 3-O-methylrhamnose present in cell walls & 0 & 0 & 0 & 100 & 100 \\
\hline Resistance to novobiocin $(50 \mu \mathrm{g} / \mathrm{ml})$ & 0 & 0 & 0 & 100 & 100 \\
\hline \multicolumn{6}{|l|}{ Growth requirement } \\
\hline Thiamine & 0 & 0 & 100 & 100 & 0 \\
\hline Methionine & 0 & 100 & 0 & 0 & 0 \\
\hline \multicolumn{6}{|l|}{$\begin{array}{l}\text { Growth on the following compounds as } \\
\text { sole carbon sources }(1 \%, \text { wt/vol }) \text { : }\end{array}$} \\
\hline D-Fructose & 0 & 0 & 100 & 100 & 100 \\
\hline Raffinose & 0 & 0 & 100 & 100 & 100 \\
\hline L-Rhamnose & 100 & 100 & 100 & 100 & 0 \\
\hline D-Mannitol & 0 & 0 & 0 & 100 & 0 \\
\hline$\alpha$-Methyl-D-glucoside & 0 & 0 & 0 & 100 & 0 \\
\hline Glycerol & 0 & 0 & 0 & 38 & 0 \\
\hline D-Ribose & 0 & 50 & 0 & 100 & 100 \\
\hline Adonitol & 0 & 0 & 0 & 38 & 0 \\
\hline myo-Inositol & 0 & 0 & 0 & 50 & 0 \\
\hline Lactose & 67 & 100 & 100 & 100 & 100 \\
\hline Melezitose & 0 & 0 & 0 & 25 & 0 \\
\hline Gluconate & 0 & 0 & 0 & 63 & 0 \\
\hline
\end{tabular}


TABLE 3. Cultural characteristics of $C$. matsumotoense $6393-\mathrm{C}^{\mathrm{T}}$ and $C$. tsunoense $6420-\mathrm{P}^{\mathrm{T}}$

\begin{tabular}{|c|c|c|c|c|c|}
\hline \multirow[b]{2}{*}{ Agar medium ${ }^{a}$} & \multicolumn{3}{|c|}{ C. matsumotoense $6393-\mathrm{C}^{\mathrm{T}}$} & \multicolumn{2}{|c|}{ C. tsunoense $6420-\mathrm{P}^{\mathrm{T}}$} \\
\hline & Growth & $\begin{array}{l}\text { Color of reverse side } \\
\text { of colonies }\end{array}$ & $\begin{array}{c}\text { Soluble } \\
\text { pigment }^{b}\end{array}$ & Growth & $\begin{array}{l}\text { Color of reverse side } \\
\text { of colonies }\end{array}$ \\
\hline Sucrose-nitrate & Poor & Colorless & & Poor & Colorless \\
\hline Glucose-asparagine & Moderate & Bamboo (2gc) & & Poor & Colorless \\
\hline Glycerol-asparagine & Poor & Colorless & & Poor & Light wheat (2ea) \\
\hline Salts-starch & Moderate & Light $\tan (3 \mathrm{gc})$ & Bisque (3ec) & Poor & Light wheat (2ea) \\
\hline Tyrosine & Poor & Colorless & Trace of brown & Poor & Bright yellow (2pa) \\
\hline Nutrient & Moderate & Mustard gold (2pe) & Trace of yellow & Moderate & Colonial yellow (2ga) \\
\hline Yeast extract-malt extract & Good & Light $\tan (3 \mathrm{gc})$ & & Good & Bright marigold $(3 \mathrm{pa})$ \\
\hline Oat meal & Good & Tile red $(5 \mathrm{ne})$ & Nude $\tan (4 \mathrm{gc})$ & Good & Bright marigold (3pa) \\
\hline Glucose-yeast extract & Good & Amber (3pe) & & Good & Pastel orange (4ic) \\
\hline Hickey-Tresner & Moderate & Bamboo $(2 \mathrm{gc})$ & & Good & Mustard gold (2pe) \\
\hline
\end{tabular}

"Aerial mycelia were not formed on all media. The preparations were incubated at $28^{\circ} \mathrm{C}$ for 3 weeks.

${ }^{b}$ For color designations see reference 4 .

agar or peptone-iron agar by $C$. ferruginea $6183-\mathrm{F}, 6423-\mathrm{A}$, 6432-C, and 6479-B, C. citrea 6188-B, and strain 6393-C $\mathrm{C}^{\mathrm{T}}$.

DNA-DNA hybridization. In the physiological tests described above, strains $6393-\mathrm{C}^{\mathrm{T}}$ and $6420-\mathrm{P}^{\mathrm{T}}$ were different from other strains tested. These strains were further compared by using DNA-DNA hybridization with the type strains of previously described Catellatospora species (Table 4). These strains exhibited low levels of homology to the other Catellatospora species tested, as well as to strains in other actinomycete genera (Micromonospora and Streptomyces).

DNA base composition. The average base composition of C. matsumotoense $6393-\mathrm{C}^{\mathrm{T}}$ DNA was $71.0 \mathrm{~mol} \% \mathrm{G}+\mathrm{C}$, and that of $C$. tsunoense $6420-\mathrm{P}^{\mathrm{T}}$ DNA was $70.6 \mathrm{~mol} \% \mathrm{G}+\mathrm{C}$.

\section{DISCUSSION}

We proposed the genus Catellatospora in 1986 (1); this genus clearly differs from other genera in the actinoplanate group in the morphology of the linear spore units formed directly from the vegetative mycelia. Two species were proposed initially (1). These organisms were identified mainly by the numbers of isoprenoid units of their menaquinones and the color of the vegetative mycelium. The names $C$. ferruginea and $C$. citrea were derived from their colors. Recently, a specific sugar, 3-O-methylrhamnose, was identified in the cell walls of the MK-10-containing strains in this genus (3). These characteristics for species identification in this genus were higher criteria than those used in other genera of bacteria. This means that determination of detailed characteristics can be helpful in recognizing taxonomic variations within this genus. In this study we compared previously described species and new isolates by examining morphology, physiology, and chemotaxonomy.

From an ecological point of view, it is interesting that all of the isolates of Catellatospora species were recovered from woodland soils collected at various places from Hokkaido in northern Japan to Yamaguchi in western Japan. No strains were isolated from sediments of lakes or rivers or from soils of agricultural fields. Strains of this genus are probably distributed widely in woodlands of temperate regions.

Among the morphological and cultural characteristics, the globose bodies observed in $C$. tsunoense $6420-\mathrm{P}^{\mathrm{T}}$ were similar to those described for members of the genus Dactylosporangium $(11,12)$. The color of the mycelial mass was a convenient characteristic for recognizing strains, but the difference in vegetative color between orange and yellow strains showed little reliability as a key characteristic for taxonomic classification.

Among the physiological characteristics, novobiocin susceptibility is a significant diagnostic factor, which shows strict correlations with the menaquinones of the species and the presence of 3-O-methylrhamnose in cell walls. C. tsunoense $6420-\mathrm{P}^{\mathrm{T}}$ is the exceptional strain in the group of strains containing $\mathrm{MK}-9$, because it requires thiamine for

TABLE 4. Levels of DNA relatedness among Catellatospora species and strains of other genera

\begin{tabular}{|c|c|c|c|c|c|}
\hline \multirow[b]{2}{*}{$\begin{array}{c}\text { Source of } \\
\text { unlabeled DNA }\end{array}$} & \multirow[b]{2}{*}{$\begin{array}{c}\text { DNA } \\
\mathrm{G}+\underset{\mathrm{C} \text { content }}{(\mathrm{mol} \%)}\end{array}$} & \multicolumn{4}{|c|}{ \% Reassociation with labeled DNA from: } \\
\hline & & $\begin{array}{l}\text { C. tsunoense } \\
6420-\mathrm{P}^{\mathrm{T}}\end{array}$ & $\begin{array}{l}\text { C. citrea subsp. } \\
\text { methionotrophica } \\
\quad 6257-\mathrm{B}^{\mathrm{T}}\end{array}$ & $\begin{array}{l}\text { C. citrea } \\
6183-\mathrm{E}^{\mathrm{T}}\end{array}$ & $\begin{array}{c}\text { C. matsumotoense } \\
6393-C^{\mathrm{T}}\end{array}$ \\
\hline C. tsunoense $6420-\mathrm{P}^{\mathrm{T}}$ & 70.6 & $(100)^{b}$ & & & \\
\hline C. citrea subsp. methionotrophica $6257-\mathrm{B}^{\mathrm{T}}$ & $70.8^{c}$ & 25 & $(100)$ & & \\
\hline C. citrea $6183-\mathrm{E}^{\mathrm{T}}$ & $70.9^{a}$ & 19 & 58 & $(100)$ & \\
\hline C. citrea $6189-\mathrm{A}$ & $\mathrm{ND}^{d}$ & 26 & 63 & 89 & \\
\hline C. matsumotoense $6393-C^{\mathrm{T}}$ & 71.0 & 24 & 29 & 34 & $(100)$ \\
\hline C. ferruginea $6257-\mathrm{C}^{\mathrm{T}}$ & $71.5^{a}$ & 28 & 22 & 24 & 28 \\
\hline Micromonospora olivasterospora ATCC $21819^{\mathrm{T}}$ & ND & 27 & 19 & 27 & 25 \\
\hline Streptomyces olivaceus ATCC 12019 & ND & 22 & 18 & 23 & 23 \\
\hline Escherichia coli B & ND & 8 & 9 & 10 & 7 \\
\hline
\end{tabular}

"Data from reference 1.

$b$ Values in parentheses indicate that, by definition, the level of reassociation was $100 \%$.

c Data from reference 2 .

${ }^{d} \mathrm{ND}$, Not determined. 
growth and uses D-fructose and raffinose as sole carbon sources. On the other hand, in the group containing MK-10 C. matsumotoense $6393-\mathrm{C}^{\mathrm{T}}$ is the exception because it does not require thiamine and is unable to utilize D-mannitol, $\alpha$-methyl-D-glucoside, and L-rhamnose.

The results of the DNA homology study showed that the proposed new species exhibit low levels of homology to previously described Catellatospora species and to each other.

Therefore, we described two new species in the genus Catellatospora, C. matsumotoense (with type strain 6393-C $[=$ IFO 14550]) and $C$. tsunoense (with type strain 6420-P [ = IFO 14552]).

The methionine-requiring organism $C$. citrea subsp. methionotrophica (2) exhibited an intermediate level of homology to $C$. citrea strains. This strain is retained as a subspecies.

Based on the results of the comparative studies described above, determinations of novobiocin susceptibility, thiamine and methionine requirements, and utilization of $\mathrm{D}$-fructose, raffinose, L-rhamnose, D-mannitol, and $\alpha$-methyl-D-glucoside are useful for rapid differentiation among the four species and one subspecies in this genus.

Descriptions of the new species are given below.

Catellatospora matsumotoense sp. nov. Catellatospora matsumotoense (ma. tsu. mo. to. en' se. L. deriv. matsumotoense, of Matsumoto Nagano, Japan, the location of the soil sample from which the type strain was isolated). The major menaquinone is $\mathrm{MK}-10\left(\mathrm{H}_{6}, \mathrm{H}_{8}\right)$. 3-O-methylrhamnose is present in the cell walls. Resistant to novobiocin $(50 \mu \mathrm{g} / \mathrm{ml})$. Does not require thiamine for growth. Utilizes L-arabinose, cellobiose, D-fructose, D-galactose, D-glucose, lactose, maltose, D-mannose, raffinose, D-ribose, starch, and D-xylose for growth. Poor to no growth on adonitol, gluconate, glycerol, D-mannitol, myo-inositol, melezitose, $\alpha$-methyl-D-glucoside, and L-rhamnose. Orange colony masses are formed on oatmeal agar and yeast extract-malt extract agar, and yellow colony masses are formed on glucose-yeast extract agar and nutrient agar. Diffusible pigments are formed (reddish brown on oatmeal agar and yellowish on salts-starch agar). No growth occurs in the presence of $3 \% \mathrm{NaCl}$. Mesophilic. Isolated from soil. The $\mathrm{G}+\mathrm{C}$ content of the DNA is $71.0 \pm$ $0.5 \mathrm{~mol} \%$ (as determined by the thermal denaturation method). The type strain of $C$. matsumotoense is strain 6393-C ( = IFO 14550).

Catellatospora tsunoense sp. nov. Catellatospora tsunoense (tsu. no en' se. L. deriv. tsunoense, of Tsuno-gun, Yamaguchi, Japan, the origin of the soil sample from which the type strain was isolated). The major menaquinone is $\mathrm{MK}-9\left(\mathrm{H}_{4}\right)$. 3-O-methylrhamnose is lacking in the cell walls. Susceptible to novobiocin $(50 \mu \mathrm{g} / \mathrm{ml})$. Requires thiamine for growth. Utilizes L-arabinose, cellobiose, D-fructose, D-galactose, D-glucose, lactose, maltose, D-mannose, raffinose, L-rham- nose, starch, and D-xylose. Poor to no growth on adonitol, gluconate, glycerol, D-mannitol, $\alpha$-methyl-D-glucoside, myoinositol, and D-ribose. Globose bodies are formed. Yellow colony mass. No soluble or melaninlike pigments are produced. No growth occurs in the presence of $3 \% \mathrm{NaCl}$. Mesophilic. Isolated from woodland soil. The $\mathrm{G}+\mathrm{C}$ content of the DNA is $70.6 \pm 0.5 \mathrm{~mol} \%$ (as determined by the thermal denaturation method). The type strain of $C$. tsunoense is strain 6420-P $(=$ IFO 14552).

\section{ACKNOWLEDGMENT}

We thank Masumi Uemura-Asano for her skillful technical assistance.

\section{LITERATURE CITED}

1. Asano, K., and I. Kawamoto. 1986. Catellatospora, a new genus of Actinomycetales. Int. J. Syst. Bacteriol. 36:512-517.

2. Asano, K., and I. Kawamoto. 1988. Catellatospora citrea subsp. methionotrophica subsp. nov., a methionine-deficient auxotroph of the Actinomycetales. Int. J. Syst. Bacteriol. 38: 326-327.

3. Asano, K., H. Sano, I. Masunaga, and I. Kawamoto. 1989. 3-O-Methylrhamnose: identification and distribution in Catellatospora and related actinomycetes. Int. J. Syst. Bacteriol. 39:56-60.

4. Container Corporation of America. 1958. Color harmony manual, 4th ed. Container Corporation of America, Chicago.

5. Hopwood, D. A., M. J. Bibb, K. F. Chater, T. Kieser, C. J. Bruton, H. M. Kieser, D. J. Lydiate, C. P. Smith, J. M. Ward, and H. Schrempf. 1985. Genetic manipulation of Streptomyces: a laboratory manual. The John Innes Foundation, Norwich, Great Britain.

6. Lechevalier, H. A., M. P. Lechevalier, and N. N. Gerber. 1971. Chemical composition as a criterion in the classification of actinomycetes. Adv. Appl. Microbiol. 14:47-72.

7. Lechevalier, M. P. 1968 . Identification of aerobic actinomycetes of clinical importance. J. Lab. Clin. Med. 71:934-944.

8. Lechevalier, M. P., A. E. Stern, and H. A. Lechevalier. 1981. Phospholipids in the taxonomy of actinomycetes, p. 111-116. In K. P. Shaal and G. Pulver (ed.), Actinomycetes. Gustav Fisher Verlag, Stuttgart.

9. Marmur, J. 1961. A procedure for isolation of deoxyribonucleic acid from micro-organisms. J. Mol. Biol. 3:208-218.

10. Marmur, J., and P. Doty. 1962. Determination of the base composition of deoxyribonucleic acid from its thermal denaturation temperature. J. Mol. Biol. 5:109-118.

11. Sharples, G. P., and S. T. Williams. 1974. Fine structure of the globose bodies of Dactylosporangium thailandense (Actinomycetales). J. Gen. Microbiol. 84:219-222.

12. Thiemann, J. E., H. Pagani, and G. Beretta. 1967. A new genus of the Actinoplanaceae: Dactylosporangium, gen. nov. Arch. Microbiol. 58:42-52.

13. Uchida, K., and K. Aida. 1977. Acyl type of bacterial cell wall: its simple identification by colorimetric method. J. Gen. Appl. Microbiol. 23:249-260. 